\title{
Editorial
}

\section{Avanço na quantidade de matriculas na Educação Brasileira}

Nos anos recentes e em 2017 houve ligeiras diminuições na quantidade de alunos matriculados na Educação Básica em relação a 2016: segundo o Censo Escolar da Educação Básica 2017 publicado pelo MEC em 2016, havia 48,8 milhões alunos no sistema educacional do país, quantidade ligeiramente maior aos 48,6 milhões registrados em 2017 atribui-se essa queda às dificuldades estruturais e gargalos da Educação neste nível uma vez que as matriculas em escolas de período integral aumentaram no período.

Os números da Educação Brasileira são grandiosos e a quantidade de alunos matriculados é maior que a população de muitos países deste Planeta. Devido ao contingente muito grande de alunos, é razoável que os processos envolvendo uma quantidade grande sejam mais complexos que aqueles que ocorrem em quantidades países com quantidades muito menores de estudantes. Os alunos da Educação Básica e suas famílias precisam de professores e profissionais formados no nível superior que atendam às necessidades da sociedade.

A Educação Brasileira também vem passando por mudanças em suas modalidades e está em evolução. No caso da Educação Superior, em 2016 o ritmo do crescimento das matrículas também se alterou: as matrículas em instituições de ensino superior subiram de 8,03 milhões em 2015 para 8,05 milhões em 2016, uma diminuição no ritmo de crescimento quando comparado aos últimos anos. conforme o Censo da Educação Superior 2017 publicado pelo INEP/MEC.

$\mathrm{Na}$ Educação Superior, as dificuldades econômicas do País associadas à falta de financiamento estudantil também não incentivaram os alunos a se matricularem e um exemplo disso é a diminuição da quantidade de matriculas no Ensino Superior Tecnológico nos anos recentes, porém a Educação a Distância manteve seu crescimento tornando-se uma modalidade consolidada, importante e em pleno desenvolvimento.

Acredita-se que por meio da recuperação econômica brasileira, os estudantes voltem a se matricular nos cursos superiores de todas modalidades nestes próximos anos. A educação não pode parar. Como já mencionamos em edições anteriores, a educação pode ser formal, 
não formal ou informal. No contexto educacional complexo do País, torna-se interessante que suas instituições e organizações que incentivem as pessoas a buscar em paralelo à educação formal, também as outras categorias que podem apoiar de alguma forma a melhoria do nível educacional do brasileiro, por meio da leitura, da atualização e do incentivo às pesquisas, avanço no conhecimento e no saber.

As revistas científicas e acadêmicas, neste contexto, podem desempenhar um papel importante, principalmente para as pessoas em idade escolar da Educação Superior, de modo a ajudar a formar um letramento importante para que no retorno aos estudos, não tenham tanta dificuldade. Também para os estudantes já inseridos nas modalidades da Educação Superior, os meios de comunicação como os periódicos mencionados também são importantes para desenvolver o saber, o envolvimento dos alunos no contexto das pesquisas e do conhecimento atual.

Para os profissionais já formados e as pessoas da sociedade em geral, as revistas podem trazer um saber atualizado e ajude a formar conceitos necessários para os avanços da sociedade. Neste sentido, torna-se importante que as pessoas leiam regularmente, e os autores tragam o saber mais atual para os leitores de seus trabalhos, seus relatos de pesquisa e enfim de seus documentos científicos.

Nós, da revista Research, Society and Development, conscientes da importância social e do papel desempenhado pelo periódico na sociedade temos nos empenhado em servir à aqueles que nos prestigiaram de alguma forma: uns enviando seus trabalhos, outros atuando como revisores e na cadeia final do processo, os leitores que são parte da sociedade, nosso objetivo maior e a quem procuramos servir com zelo.

Nosso objetivo, como temos afirmado e confirmado, é disseminar o saber na sociedade uma vez que acreditamos que por meio dele é possível se alcançar uma condição de vida melhor para todos por meio do letramento e do conhecimento e desta forma, pedimos que nos continuem ajudando a disseminar o saber sobre a revista e seu conteúdo e desta forma, vamos juntos tentando superar as dificuldades dos tempos atuais.

Desejamos a todos, boa leitura e construção do saber útil à sociedade.

\author{
Dr. Ricardo Shitsuka
}

Editor 